\title{
POINT OF VIEW
}

\section{THE NEED TO ABOLISH THE DEATH PENALTY}

De Alwis L.B.L

Retired Chief Consultant Judicial Medicine Officer, Colombo, Sri Lanka

The death penalty or Capital punishment or judicial hanging or sending to the "Gallows" is the killing of a person by legal statute. In this situation the head of state is literally the executioner as he gives the final order for execution, including the date, time and the place of execution. Thus the state legalizes, solemnizes and sanctifies the act of termination of a human life.

In Sri Lanka offences for which the death penalty is applicable include. ${ }^{1}$

(a) Murder and conspiracy to murder

(b) Abetment of suicide when such person commits suicide.

(c) Possession of 2 or more grams of Heroin.

Several other offenses for which the death penalty is applicable in other countries are not applicable in Sri Lanka.

Hanging by the neck is the only mechanism used to cause death in the judicial setting in Sri Lanka as proclaimed by the British after they took control of the island in $1815 .^{2}$

The death penalty which may be implemented by "hanging" or any other means amply describes and explains the cruelty of the death sentence. Amnesty international in 1990 described the death penalty as "cruel, inhuman and degrading".3,4 There is mental torture for the person sentenced to death for several days, weeks or months before the date of execution. Further there is physical torture during execution. What about the mental torture afflicted on the next of kin, mainly the innocent wife, children, parents, many of who become destitute. Does the state who took the life of the prisoner take care of the dependents?

As a judicial medical officer working in the Ministry of Health for 32 years, I have given evidence in several hundreds' of murder trials where the accused may very well have been sentenced to death. However, I am much relieved that such death sentences have not been executed.

All articles in Sri Lanka Journal of Forensic Medicine, Science \& Law are licensed under the terms of the licensed under a Creative Commons Attribution-Non Commercial 4.0 International License. 
Most prosecuting counsel believe that society demands accountability from the state for such terrible crimes and that the murderer when convicted forfeit the right to live in that society. They also believe that the death penalty is the only mechanism to protect innocent human lives from murderers.

Does the prosecution and civil society organizations who clamour for the implementation of the death penalty ever reflect that the murderer is another human being, living in the same society, misguided by that society which nurtured the prosecution and those who demand implementation of the death penalty.

If the prosecuting counsel and convicting judges and civil society organizations ever visit the "Gallows", to witness an execution and see the pathetic state of a man dead (or at times struggling) I am confident that they will never ever sentence to death a man by hanging but will certainly opt for life imprisonment.

The death penalty as a deterent to murder has no support, as research carried by states where the death penalty is used as a punishment for murder indicates the negative. Such research carried out mainly in the U.S.A where the death penalty is implemented by several methods indicate a much higher murder rate which is further proof that the death penalty is not a deterent to murder. ${ }^{5}$

The British Commission on capital punishment noted that the capital punishment obviously failed as a determent for grave crimes such as murder. ${ }^{6}$

Another argument in favour of the implementation of the death penalty is based on retribution. Here the concept is that evil can be countered by appropriate punishment. But this is not retribution but simply revenge of a highest order like the Bibilical saying "Eye for an Eye or a tooth for a tooth". In the context of the death penalty it simply means life for a life. Such revenge and retaliation for murder cannot be accepted in modern civilized society.

Legal argument for abolition of the death penalty includes:

(a) Most murders are not premeditated and there was no criminal intent.

(b) Erroneous convictions. In other words innocent person have paid with their lives for murders committed by others. Most erroneous convictions are due to mistaken identify and false evidence, where the actual murderer becomes a crown witness and the chief witness for the prosecution.

Even if a single prisoner is executed by an erroneous conviction, that itself is a valid reason for the abolition of the death penalty. Studies in USA have revealed that the likely number of executions by erroneous judgments are about $4 \% .^{7}$ It is often stated in legal parlance that it is better to send home 99 murderers than to convict and execute one single innocent man on a charge of murder. How many such innocent persons have been executed to date? Several persons convicted of murder and sentenced to death have been exonerated later on DNA evidence. In Sri Lanka how many murder convicts can have access to DNA technology when they are wrongfully found guilty of murder and sentenced to death? DNA studies have exposed the fallibility of the criminal justice system. ${ }^{8}$

In Sri Lanka inherent legal defects leading to wrongful convictions for murder include:

(a) Wrongful indictment for murder.

(b) Murder suspect not "adequately" represented by counsel.

(c) Non-representation of accused by lawyers in certain types of murder cases.

(d) Failure of defense counsels and judges to seek second opinions in respect of medical and scientific evidence which is dubious.

(e) Failure to obtain a report from a psychiatrist as to the mental state of the 
accused at the time of committing the murder.

(f) Judicial errors - all judges are human and are fallible.

(g) Perverted jury verdicts - a divided jury verdict of 5 to 2 where there is a reasonable doubt the verdict is sufficient to sentence a person to death on a murder charge.

Every human being has a right to life, both the victim and the murderer. The death penalty is clearly in violation of the right to life and right to live. The Universal declaration of Human Rights in 1948, proclaimed that "every individual has a right to life, liberty and security of his person. ${ }^{9}$ Amnesty International in 1977 and other civil organizations called for the abolition of the death penalty.

Sri Lanka did not abolish the death penalty but retained the death penalty in its legal statutes. However Sri Lanka did not carry out the death penalty as a government policy since 1956. The re-implementation of the death sentence in 1961 to punish the three murderers of the then Prime Minister resulted in 89 person being executed by hanging. Subsequently, it was once again not carried out since 1976. Today there are nearly 1000 prisoners on death row in Sri Lanka, awaiting execution. All of them are at the mercy of the executive who decides on the life and death of such convicts. The Morris Commission of Ceylon established in 1958 strongly argued for the abolition of the death penalty as it was totally against the Buddhist tradition of tolerance and compassion.

If the death penalty is to be abolished, there must be an alternative to it. British Governor Sir Joseph West Ridgway commuting the death sentence to life imprisonment stated "it compels me to remit the extreme death penalty which would close the door for further inquiring and reparation should the doubt be confirmed by future revelation.
In the Roman Treaty of 1998, the international Criminal Court stated that the maximum penalty should be life imprisonment even for the worst crimes against humanity such as gruesome murders, genocide, rape and murder and torture and murder.

Life imprisonment in Sri Lanka means imprisonment for 20 years with hard labour. However, they can be released by the executive after 20 years or before 20 years. This punishment is not a deterent to murder. The alternative punishment is imprisonment for life where the convicted prisoner spend the rest of his life in a prison environment without parole. Such convicts can undergo counselling, psychiatric treatment if necessary, be given a suitable education, placed in a religious background of their choice, receive vocational training and thereafter be rehabilitated in an open prison environment. This would be beneficial to the convict, his family and to the country. The 1962 survey in the United Nations also showed that "imprisonment for life" for convicted murderers is sufficient protection for society. Furthermore, those who are convicted but later exonerated may be awarded compensation.

The declaration of the World Medical Association (WMA) in 1977 at Stockholm stated: that the death penalty is the ultimate, cruel, inhuman and degrading punishment for a human being as it violates the right to life and that it is totally and unconditionally opposed to the death penalty and calls upon all governments to bring about the immediate and total abolition of the death penalty. ${ }^{10}$

Implementation of the death penalty is a journey of no return to an innocent man. Universal abolition of the death penalty will be one of the most beautiful victories of humanity. ${ }^{11}$ 


\section{REFERENCES}

1. Penal Code. An ordinance to provide a general penal code for Ceylon. Chapter 19: 371. [cited 2018 Jun 10]. Available from: http://hrlibrary.umn.edu/research/srilanka/st atutes/Penal_Code.pdf

2. Pippet GK. A History of the Ceylon Police: 1795-1870. Times of Ceylon. 1938.

3. Amnesty International Report 1977. London (UK): Amnesty International Publications; 1977.

4. Amnesty International Report 1990. London (UK): Amnesty International Publications; 1990.

5. Bedau HA. The case against the death penalty. Washington: American Civil Liberties Union; 1973.

6. Wingersky MF. Report of the royal commission on capital punishment (19491953): A review. The Journal of criminal law, criminology, and police science. 1953; 44:695.
7. Gross SR, O'Brien B, Hu C, Kennedy EH. Rate of false conviction of criminal defendants who are sentenced to death. Proceedings of the National Academy of Sciences. 2014: 201306417. DOI: https://doi.org/10.1073/pnas.1306417111

8. Innocence Project [Internet]. [Updated 2017; cited 2018 Jun 10]. Available from: https://www.innocenceproject.org/

9. Assembly UG. Universal declaration of human rights. Australia: UN General Assembly; 1948.

10. Declaration of Stockholm. Amnesty International Conference on the Abolition of the Death Penalty, 1977.

11. Moldrich D. Hangman, Spare that Noose: A Historical and Analytical Survey of the Death Penalty with Special Reference to Sri Lanka. 1983. 